\title{
PROFESI GURU DAN KOMPETENSI YANG HARUS DIMILIKI
}

\author{
Widyana Kartika Putri \\ Email: widyana141@gmail.com \\ Program Studi Pendidikan Sejarah Fakultas Keguruan dan Ilmu Pendidikan \\ Universitas Lambung Mangkurat \\ Banjarmasin
}

\begin{abstract}
Abstrak
Profesi guru adalah keahlian dan kewenangan khusus dalam bidang pendidikan, pengajaran, dan pelatihan yang ditekuni untuk menjadi mata pencaharian dalam memenuhi kebutuhan hidup yang bersangkutan. Guru termasuk sebagai suatu profesi dikarenakan guru memiliki keahlian khusus dan tidak dapat dilakukan sembarang orang diluar pendidikan serta syarat dan kriteria yang memenuhi untuk dapat dikatakan sebagai profesi. Profesionalisme guru sangat penting untuk diperhatikan, ini karena profesionalisme akan mempengaruhi kualitas pendidikan yang ada. Guru juga diharuskan memiliki 4 kompetensi pokok yang dimana itu merupakan satu kesatuan agar dapat disebut sebagai guru yang profesional, diantaranaya ialah kompetensi profesional, kompetensi sosial, kompetensi pedagogik, dan kompetensi kepribadian.
\end{abstract}

\section{PENDAHULUAN}

Profesi secara etimologi berasal dari kata profession (inggris) yang berasal dari bahasa Latin profesus yang berarti "mampu atau ahli dalam suatu bentuk pekerjaan". Profesi dapat diartikan sebagai suatu pekerjaan atau jabatan yang menuntut keahlian, yang didapat melalui pendidikan dan latihan tertentu, menurut persyaratan khusus memiliki tanggung jawab dan kode etik tertentu (Susanto, 2020: 13).

Dalam UU RI No.14 tahun 2005 tentang guru dan dosen pasal 1, Guru adalah pendidik profesional dengan tugas utama mendidik, mengajar, membimbing, mengarahkan, melatih, menilai, dan mengevaluasi peserta didik pada pendidikan anak usia dini jalur pendidikan formal, pendidikan dasar, dan pendidikan menengah (Susanto, 2020: 16).

Dari penjelasan sebelumnya dapat diartikan profesi guru adalah keahlian dan kewenangan khusus dalam bidang pendidikan, pengajaran, dan pelatihan yang ditekuni untuk menjadi mata pencaharian dalam memenuhi kebutuhan hidup yang bersangkutan (Zubaidah, 2014: 1).

Penjelasan-penjelasan di atas saya mengartikan bahwa profesi itu melihat pekerjaan berdasarkan keahlian khusus yang dimiliki masing-masing orang. Selain terdaapat persyaratan khusus untuk sebuah profesi sesuai dengan bidangnya. Profesi guru berarti 
pekerjaan yang di mana memiliki keahlian khusus dibidang pendidikan, akan tetapi guru memiliki keahlian khusus sendirinya, seperti misalnya mata pelajaran yang dikuasai guru berbeda-beda sesuai dengan apa yang telah mereka lalui di pendidikan tinggi yang mereka jalani.

\section{PERAN GURU SEBAGAI SEBUAH PROFESI}

Guru dapat digolongkan sebagai sebuah profesi ini dikarenakan guru memiliki keahlian khusus dan tidak dapat dilakukan oleh sembarang orang diluar bidang pendidikan. Selain itu, guru memenuhi syarat-syarat khusus dan kriteria sehingga dapat digolongkan sebagai suatu profesi. Menurut National Education Association (NEA), syarat guru sebagai profesi terpenuhi karena memiliki kriteria: jabatan yang melibatkan kegiatan intelektual, jabatan yang menggeluti suatu batang tubuh ilmu yang khusus, jabatan yang memerlukan persiapan professional yang lama (bandingkan dengan pekerjaan yang memerlukan latihan umum belaka), jabatan yang melibatkan memerlukan latihan dalam jabatan yang berkesinambungan, jabatan yang menjanjikan karier hidup dalam keanggotaan yang permanen, jabatan yang lebih mementingkan layanan di atas keuntungan pribadi, dan jabatan yang mempunyai organisasi profesional yang kuat dan terjalin erat (Susanto, 2020: 19).

Itulah mengapa guru dapat dikategorikan sebagai suatu profesi, karena guru sendiri memiliki keahlian khusus serta guru sendiri sudah memenuhi persyaratan khusus seperti profesi lainnya yang dapat di masukkan ke dalam suatu profesi, seperti yang disebut oleh National Education Association (NEA) guru memenuhi semua kriteria yang dituliskan.

Menurut UU RI No. 14 tahun 2005 tentang Guru dan Dosen, Guru adalah pendidik profesional dengan tugas utama mendidik, mengajar, membimbing, mengarahkan, melatih, menilai, dan mengevaluasi peserta didik pada pendidikan anak usia dini jalur pendidikan formal, pendidikan dasar, dan pendidikan menengah. Dosen adalah pendidik profesional dan ilmuan dengan tugas utama mentransformasikan, mengembangkan, dan menyebarluaskan ilmu pengetahuan, teknologi, dan seni melalui pendidikan, penelitian, dan pengabdian kepada masyarakat (Susanto, 2020: 16).

Hak guru pada UU No.14 tahun 2005 tentang guru dan dosen pasal 14 yaitu: memperoleh penghasilan di atas kebutuhan hidup minimum dan jaminan kesejahteraan sosial; mendapatkan promosi dan penghargaan sesuai dengan tugas dan prestasi kerja; memperoleh perlindungam dalam melaksanakan tugas dan hak atas kekayaan intelektual; memperoleh kesempatan untuk meningkatkan kompetensi; memperoleh dan memanfaatkan sarana dan prasaranan pembelajaran untuk menunjang kelancaran tugas keprofesionalan; memiliki kebebasan dalam memberikan penilaian dan ikut menentukan kelulusan, penghargaan, dan atau sanksi kepada peserta didik sesuai dengan kaidah pendidikan, kode etik guru, dan peraturan perundang-undangan; memperoleh rasa aman dan jaminan keselamatan dalam melaksanakan tugas; memiliki kebebasan untuk berserikat dalam 
organisasi profesi; memiliki kesempatan untuk berperan dalam penentuan kebijakan pendidikan; mempwroleh kesempatan untuk mengembangkan dan meningkatkan kualifikasi akademik dan kompetensi; memperoleh pelatihan dan pengembangan profesi dalam bidangnya. (Susanto, 2020: 44-45).

Kemudian kewajiban guru menurut UU No.14 tahun 2005 tentang guru dan dosen pasal 20 adalah sebagai berikut: merencanakan pembelajaran, melaksanakan proses pembelajaran yang bermutu, serta menilai dan mengevaluasi hasil pemeblajaran; bertindak objektif dan tidak diskriminatif atas dasar pertimbangan jenis kelamin, agamm, suku, ras, dan kondisi fisik tertentu, atau latar belakang keluarga, dan status sosial ekomomi peserta didik dalam pembelajaran; memelihara dan memupuk persatuan dan kesatuan bangsa; menjunjung tinggi peraturan perundang undangan, hukum dan kode etik guru, serta nilainilai agama dan etika; mengembangkan dan meningkatkan kualifikasi akademik dan kompetensi secara berkelanjutan sejalan dengan perkembanhan ilmu pengetahuan, teknologi dan seni (Susanto, 2020: 47-48).

Menurut Djamarah (2000: 42-49) menyebutkan peranan yang ada pada guru seperti menjadi korektor, inspirator, informan, organisator, motivator, inisiator, fasilitator, pembimbing, demonstrator, pengelola kelas, mediator, supervisor, dan evaluator (Susanto, 2020: 39-44).

Dari penjelasan sebelumnya ini dapat diartikan bahwa guru memiliki banyak peranan, selain menjadi pendidik yang profesional. Guru juga dapat sebagai motivator dan lain sebagainya, ini membuat guru disebut juga sebagai pahlawan yang tak kenal pamrih. Selain itu setiap pekerjaan memiliki hak dan kewajiban, sama seperti profesi guru juga memilikinya seperti yang disebutkan di atas mengenai apa saja hak dan kewajiban yang ada pada guru.

\section{GURU INDONESIA DAN TANTANGAN PROFESIONALISME}

Dalam hal ingin memajukan pendidikan Indonesia ada yang perlu diperhatikan, yaitu tingkat profesionalisme guru. Ini karena jika profesionalisme guru baik maka akan dapat meningkatkan kualitas pendidikan di Indonesia. Karena keduanya saling berkaitan antara profesionalisme guru dengan kualitas pemdidikan di Indonesia.

Dalam PP No.19 tahun 2005 tentang Standar Nasional Pendidikan, pasal 28 yang di mana disebutkan bahwa "pendidik harus memiliki kualifikasi akakdemik dan kompetensi sebagai agen pembelajaran, sehat jasmani dan rohani, serta memiliki kemampuan untuk mewujudkan tujuan pendidikan nasional". Guru yang memenuhi persyaratan khusus tentang profesionalisme guru seperti yang disebutkan di atas akan dapat mengubah guru yang awalnya pasif menjadi guru yang kreatif dan dinamis sehingga profesionalisme guru ini pun diharapkan dapat berkembang (Mustofa, 2007: 78-79). 
Seorang guru memiliki 4 kompetensi pokok yang harus dimiliki yaitu kompetensi profesional, kompetensi pedagogik, kompetensi sosial, dan kompetensi kepribadian. Keempat kompetensi pokok ini berjalan beriringan sehingga seorang guru tidak dapat hanya menguasai salah satu diantaranya karena guru dapat dikatakan profesional jika dapat memiliki empat kompetensi pokok tersebut. Seperti yang tertulis mengenai kompetensi pokok profesi guru yang diatur dalam Undang-undang No. 14 tahun 2005 tentang guru dan dosen menggariskan kompetensi pokok yang harus dimiliki guru. Kompetensi itu diantaranya: kompetensi profesional, kompetensi pedagogik, kompetensi sosial, dan kompetensi kepribadian. (Susanto, 2020: 62).

Dari penjelasan di atas, dapat diketahui bahwa guru yang profesional adalah guru yang memiliki 4 kompetensi tersebut, dengan guru menguasainya dengan benar maka ada kemungkinan terciptanya kualitas pendidikan yang lebih baik dari sebelumnya dan akhirnya dapat memajukan pendidikan di Indonesia juga.

\section{SIMPULAN}

Profesi secara etimologi berasal dari kata profession (inggtis) yang berasal dari bahasa Latin profesus yang berarti "mampu atau ahli dalam suatu bentuk pekerjaan". Menurut UU RI No.14 tahun 2005 tentang Guru dan Dosen pasal 1, guru adalah pendidik profesional dengan tugas utama mendidik, mengajar, membimbing, mengarahkan, melatih, menilai, dan mengevaluasi peserta didik pada pendidikan anak usia dini jalur pendidikan formal, pendidikan dasar, dan pendidikan menengah. UU No.14 tahun 2005 tentang Guru dan Dosen pada pasal 14 mengatur tentang hak guru, sedangkan pasal 20 menyebutkan mengenai kewajiban seorang guru. Profesionalisme pada guru berhubungan dengan kualitas pendidikan, maka guru diharapkan dapat memenuhi persyaratan khusus tentang profesionalisme pada guru agar dapat memajukan pendidikan Indonesia. Guru dikatakan profesional jika memiliki kompetemsi pokok yaitu kompetensi profesional, kompetensi pedagogik, kompetensi sosial, dan kompetensi kepribadian.

\section{REFERENSI}

Efendi, I., Prawitasari, M., \& Susanto, H. (2021). Implementasi Penilaian Pembelajaran Pada Kurikulum 2013 Mata Pelajaran Sejarah. Prabayaksa: Journal of History Education, 1(1), 21-25.

Susanto, H. (2020). Profesi Keguruan. Banjarmasin: FKIP Universitas Lambung Mangkurat. 
Susanto, H., \& Akmal, H. (2018). Efektivitas Penggunaan Aplikasi Pembelajaran Berbasis Mobile Smartphone Sebagai Media Pengenalan Sejarah Lokal Masa Revolusi Fisik Di Kalimantan Selatan Pada Siswa Sekolah Menengah Atas. HISTORIA: Jurnal Program Studi Pendidikan Sejarah, 6(2), 197-206.

Susanto, H., Irmawati, I., Akmal, H., \& Abbas, E. W. (2021). Media Film Dokumenter Masuknya Islam Ke Nusantara dan Pengaruhnya Terhadap Keterampilan Berpikir Kritis Siswa. HISTORIA: Jurnal Program Studi Pendidikan Sejarah, 9(1).

Syaharuddin, S., \& Susanto, H. (2019). Sejarah Pendidikan Indonesia (Era Pra Kolonialisme Nusantara sampai Reformasi). Banjarmasin: FKIP Universitas Lambung Mangkurat.

Zubaidah. (2014). Profesionalitas Guru Fiqih Dalam Proses Pembelajaran di MTs dan MA Miftahul Ulum Ngemplak Kecamatan Mranggen Kabupaten Demak. Skripsi. Fakultas Ilmu Tarbiyah Dan Keguruan. Institut Agama Islam: Semarang.

Mustofa. (2007). Upaya Pengembangan Profesionalisme Guru Di Indonesia. Jurnal Ekonomi \& Pendidikan, 4(1). 